\title{
Crop rotation and tillage system on the Italian ryegrass seed bank after long-term field
}

\section{management}

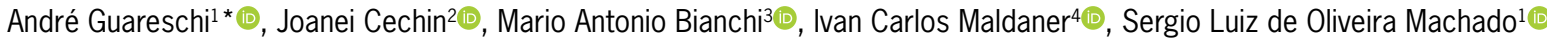

\author{
UUniversidade Federal de Santa Maria/CCR - Depto. de \\ Defesa Fitossanitária, Av. Roraima 1000 - Sala 3231 - \\ 97105-900 - Santa Maria, RS - Brasil. \\ 2Universidade Federal de Pelotas/FAEM - Depto. de \\ Fitossanidade, Campus Capão do Leão, s/n., C.P. 354 - \\ 96010-900 - Pelotas, RS - Brasil. \\ ${ }^{3}$ Cooperativa Central Gaúcha LTDA/CCGL-Tec - Depto. de \\ Plantas de Lavoura, Rod. RS 342, km 149, C.P. 10 - 99005 - \\ 970 - Cruz Alta, RS - Brasil. \\ ${ }^{4}$ Instituto Federal Farroupilha - Depto, de Agricultura, R. Vinte \\ de Setembro, 2616 - 97420-000 - São Vicente do Sul, \\ RS - Brasil. \\ *Corresponding author <andreguar@gmail.com>
}

Edited by: Lincoln Zotarelli

Received October 01, 2019

Accepted March 03, 2020

\begin{abstract}
Italian ryegrass (Lolium multiflorum Lam.) is a troublesome weed widely found in temperate Brazilian fields with several herbicide-resistant populations. Soil seed bank is the main source of future infestations and can be strongly affected by agricultural practices, such as crop rotation and tillage system. Therefore, this study evaluated the long-term effects of different crop rotation and tillage systems on the seed bank of Italian ryegrass. Data were collected in 2012 and 2013 in a field managed since 1985 under conventional-tillage and no-tillage and subjected to three cropping systems (monoculture, total, and partial rotation) compared to the control plot. The samples were collected at three soil depths $(0-5,5-10$, and 10-20 cm) using a cylindrical soil sampler, and infestations in the field were evaluated with a sample frame of $1 \mathrm{~m}^{2}$. All cropping systems reduced the soil seed bank of Italian ryegrass, regardless of soil management and sampling depths comparing to the control plot. Total and partial rotation were more effective than soil tillage to reduce the seed bank. A larger number of seeds was observed on the surface layer $(0-5 \mathrm{~cm})$ for all cropping systems with more uniform distribution in the soil profile in conventional-tillage. Infestation of Italian ryegrass was greater for monoculture under no-tillage in both years, whereas in total and partial rotation, regardless of soil tillage, infestations remained below 40 seedlings $\mathrm{m}^{-2}$. Thus, strategies to reduce the soil seed bank and infestations of Italian ryegrass should focus on cropping systems with crop rotation and no-tillage.
\end{abstract}

Keywords: Lolium multiflorum Lam., dynamic population, cultural methods, mechanical practices, weed control

\section{Introduction}

Weeds are a major problem for agricultural areas causing yield reduction and economic losses worldwide. In cropping systems, weed vegetation is mainly composed of annual species that are highly dynamic and strongly affected by agricultural practices, such as crop rotation and tillage system (Armengot et al., 2017). Weed infestations have the soil seed bank as the principal source, in which the presence of viable seeds represents a potential target for management (Norris, 2007). Effective methods of weed management should prevent seed production and promote exhaustion of soil seed bank (Chauhan et al., 2006).

In agricultural systems, non-chemical control involves the creation of unfavorable environments for weed germination and establishment in the field, reducing weed seed replenishment in the soil seed bank (Shaner and Beckie, 2014). Other practices, such as herbicidemanagement on crops and weeds, tillage frequency, and environmental conditions also influence weed seed density in the soil, reflecting the cropping history and future conditions to manage (Blackshaw et al., 2001; Davis et al., 2006; Norsworthy et al., 2012). However, recent studies reported several changes in the weed community composition and increase of grass species in many countries, such as Australia (Owen et al., 2014), the United States (Karn and Jasieniuk, 2017), and Denmark (Scherner et al., 2016) due to weed herbicide-resistance.

In agricultural fields in Brazil, Italian ryegrass is a troublesome winter annual grass in wheat and barley crops (Vargas and Roman, 2005), with several cases of herbicide-resistance. Recently, studies have reported more than 4 million ha with cases of simple, cross and multiple herbicide-resistance in Italian ryegrass populations (Vargas et al., 2016). Furthermore, the high reproductive potential of Italian ryegrass with plants that can produce up to 10,000 viable seeds after ripening, greatly contributes to seed bank replenishment (Fernández-Moreno et al., 2017).

The obstacles of chemical control, due to herbicide-resistance, requires the adoption of alternative control methods of Italian ryegrass populations, usually used when the resistant-population levels are critical, contributing to the reduction of the soil seed bank (Collavo et al., 2013; Harker and O'Donovan, 2013). Alternative practices include crop rotation, soil cultivation, competitive crops, and weed seed collection and destruction (Harker, 2013). Integrated approaches offer better opportunities for long-term control of Italian ryegrass and management of soil seed bank, allowing to reducing drastically the herbicide applications. Thus, this study evaluated the effects of crop rotation and tillage systems on the Italian ryegrass population and soil seed bank after long-term field management.

\section{Materials and Methods}

\section{Study site}

The experiment was carried out from Oct 2011 to Oct 2013 in Cruz Alta, Rio Grande do Sul State, southern 


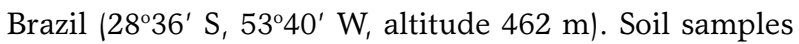
were collected from a large-scale experiment developed since 1985 on soil tillage and crop rotation (Ruedell, 1995), showed in Figure 1.

For 27 years, the fields were subdivided in blocks with $400 \mathrm{~m}^{2}$ under two tillage systems (conventional tillage and no-tillage) and three crop rotation systems (Table 1) in a soil classified as Oxisol (Soil Survey Staff, 2014). The effects of treatments were compared to the control plot $\left(\mathrm{M}_{4}\right)$, in terms of forage to animal grazing during the winter season and soybean cultivation in the summer season. The long-term average annual rainfall Cruz Alta is $1,500 \mathrm{~mm}$; howver, during the growing seasons the rainfall was 1,800 and $1,500 \mathrm{~mm}$ for 2012 and 2013 year, respectively (Brazilian Meteorological Service - INMET). Rainfall and mean temperature during the experiments are shown in Figure 2.

\section{Field management}

The crop rotation experiment included three systems: $M_{1}$ (wheat and soybean in monoculture during the winter and summer seasons, respectively), $M_{2}$ (total rotation including black oat/soybean/black oat+vetch/ corn/fodder radish/wheat/soybean), $\mathrm{M}_{3}$ (partial rotation with black oat/soybean/wheat/soybean/black oat/ soybean) compared to $M_{4}$, composed of winter grazing with Italian ryegrass and soybean in the summer season (Table 1).

The field in Cruz Alta was regularly fertilized with chemical fertilizers and sprayed with herbicides in each season since 1985. For the conventional system, soil preparation was performed with mouldboard ploughing at $20 \mathrm{~cm}$ depth, followed by harrowing before the sowing of summer crops. For the no-tillage system, glyphosate (360 g a.e. $\mathrm{L}^{-1}$ ) was used for burndown all years until 2007, while in the last five years, the field was managed with an application of glyphosate herbicide followed by paraquat (sequential) before sowing (Table 2).

Chemical management of wheat included the spray of metsulfuron-methyl (600 g a.i. $\mathrm{kg}^{-1}$ ) until 2001 applied at $2.4 \mathrm{~g}$ a.i. $\mathrm{ha}^{-1}$ and iodosulfurom-methyl $(50 \mathrm{~g}$ a.i. $\mathrm{kg}^{-1}$ ) applied at $5 \mathrm{~g}$ a.i. ha ${ }^{-1}$ after 2007 year. In corn, atrazine (500 g a.i. $\left.\mathrm{L}^{-1}\right)$ was applied at 1,500 g a.i. ha ${ }^{-1}$, and nicosulfuron (40 g a.i. $\left.\mathrm{L}^{-1}\right)$ at $60 \mathrm{~g}$ a.i. ha $\mathrm{h}^{-1}$ always sprayed in post-emergence since the beginning of the experiment. For conventional soybean, chemical control
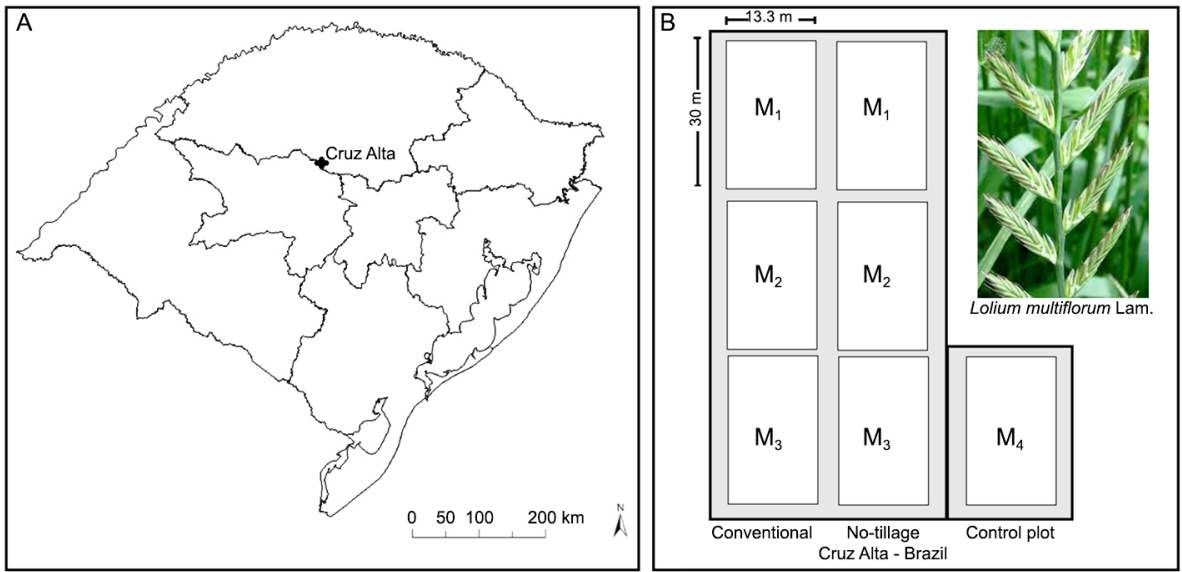

Figure 1 - Study sites (A) and schemes of the experimental design (B). In each plot, ten samples with three subsamples each were collected with a cylindrical soil sampler in three different depths.

Table 1 - Cropping systems used in the fields with differential tillage systems.

\begin{tabular}{|c|c|c|}
\hline Cropping system & Crop winter & Crop summer \\
\hline $\mathrm{M}_{1}$ - Monoculture & $\begin{array}{l}\text { Year 1: Wheat } \\
\text { Year 2: Wheat } \\
\text { Year 3: Wheat }\end{array}$ & $\begin{array}{l}\text { Year 1: Soybean } \\
\text { Year 2: Soybean } \\
\text { Year 3: Soybean }\end{array}$ \\
\hline $\mathrm{M}_{3}$ - Partial rotation & $\begin{array}{l}\text { Year 1: Black oat } \\
\text { Year 2: Wheat } \\
\text { Year 3: Black oat }\end{array}$ & $\begin{array}{l}\text { Year 1: Soybean } \\
\text { Year 2: Soybean } \\
\text { Year 3: Soybean }\end{array}$ \\
\hline $\mathrm{M}_{4}$ - Pasture in the winter with monoculture in the summer season* (Control plot) & $\begin{array}{l}\text { Year 1: Italian ryegrass pasture } \\
\text { Year 2: Italian ryegrass pasture } \\
\text { Year 3: Italian ryegrass pasture }\end{array}$ & $\begin{array}{l}\text { Year 1: Soybean } \\
\text { Year 2: Soybean } \\
\text { Year 3: Soybean }\end{array}$ \\
\hline
\end{tabular}

${ }^{\star}$ Pasture obtained from natural reseeding every winter season. 
Table 2 - Herbicides used for weed control in fields with differential cropping and tillage systems.

\begin{tabular}{|c|c|c|c|c|}
\hline Management phase & Crop & 1985 to 2000 & 2001 to 2007 & 2008 to 2013 \\
\hline Pre-emergence of the crop (Burndown) & Burndown & Glyphosate & Glyphosate & $\begin{array}{l}\text { Glyphosate } \\
\text { Paraquat }\end{array}$ \\
\hline \multirow{6}{*}{ Post-emergence of the crop } & Soybean & $\begin{array}{l}\text { Clethodim } \\
\text { Imazethapyr } \\
\text { Fomesafen } \\
\text { Lactofen } \\
\text { Bentazon }\end{array}$ & Glyphosate & Glyphosate \\
\hline & Corn & $\begin{array}{l}\text { Atrazine } \\
\text { Nicosulfuron }\end{array}$ & $\begin{array}{l}\text { Atrazine } \\
\text { Nicosulfuron }\end{array}$ & $\begin{array}{l}\text { Atrazine } \\
\text { Nicosulfuron }\end{array}$ \\
\hline & Wheat & Metsulfuron & $\begin{array}{l}\text { lodosulfuron } \\
\text { Metsulfuron } \\
\text { Clodinafop }\end{array}$ & $\begin{array}{l}\text { lodosulfuron } \\
\text { Metsulfuron } \\
\text { Clodinafop }\end{array}$ \\
\hline & Fodder radish & - & - & - \\
\hline & \multicolumn{4}{|l|}{ Black oat+vetch } \\
\hline & Black oat & - & - & - \\
\hline
\end{tabular}

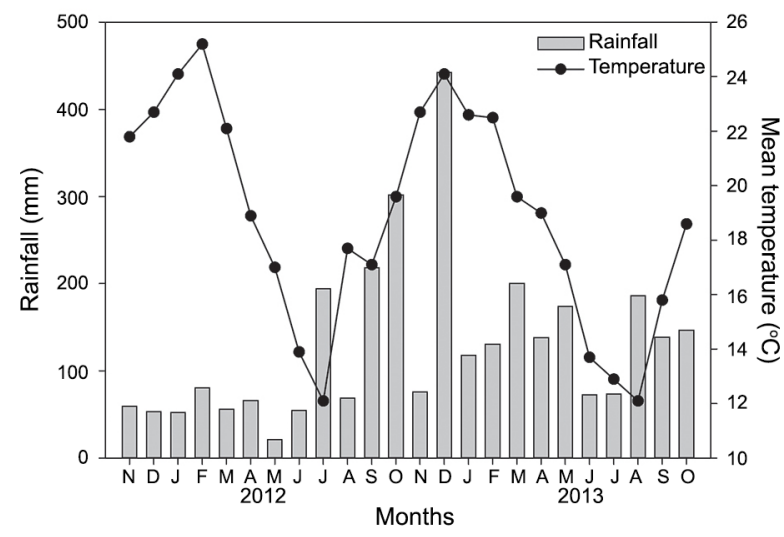

Figure 2 - Meteorological conditions during the experiment of crop rotation and tillage systems.

in post-emergence was performed with imazethapyr (100 g a.i. $\left.\mathrm{L}^{-1}\right)$, fomesafen (250 g a.i. $\left.\mathrm{L}^{-1}\right)$, lactofen $(240$ g a.i. $\left.\mathrm{L}^{-1}\right)$, bentazon (600 g a.i. $\left.\mathrm{L}^{-1}\right)$, chlorimuron-ethyl (250 g a.i. $\left.\mathrm{L}^{-1}\right)$, and clethodim (240 g a.i. $\left.\mathrm{L}^{-1}\right)$ using 100 , $250,180,720,20$, and $96 \mathrm{~g}$ a.i. ha ${ }^{-1}$, respectively. After the year 2000, Roundup Ready cultivars and glyphosate treatment using $1,080 \mathrm{~g}$ a.e. $\mathrm{ha}^{-1}$ was performed. For black oat, radish and black oat + vetch crops, the field was burned down and managed without post-emergence herbicide treatments. In the control plot $\left(M_{4}\right)$, pasture was managed without herbicides, and for soybean sowing, the field was burned down with glyphosate and clethodim at ripening of Italian ryegrass seeds, using 1,080 g a.e. +400 g a.i. ha ${ }^{-1}$, respectively.

\section{Soil seed bank sampling and Italian ryegrass population assessment}

Soils were sampled in Feb of each year (2012 and 2013), before the emergence of Italian ryegrass plants. The soil seed bank was evaluated through soil samples of each management system using a cylindrical soil sampler, with $5 \mathrm{~cm}$ diameter in ten random points of every plot.
In each point, three subsamples were collected to form a composite sample at three different depths $10-5 \mathrm{~cm}$, $5-10 \mathrm{~cm}$, and $10-20 \mathrm{~cm}$ ) following the recommended methodology for seed bank studies (Voll et al., 2003). The soil seed bank was estimated by seedling emergence and seed extraction methods (Price et al., 2010). Soil samples were placed in plastic pots to germinate in a greenhouse for 90 days, and emergence was evaluated every 15 days and by hand pulling the seedlings emerged. Soil moisture was kept at field capacity and frequent soil disturbance to stimulate seed germination (Brown, 1991).

After this period, soil samples were washed with water using a nylon sieve (120 mesh) to separate seeds and detect viable seeds that could be dormant. Italian ryegrass seeds were identified and counted with a magnifier, submitted to sterilization in alcohol $(70 \%)$ for $5 \mathrm{~min}$, sodium hypochlorite $(2 \%)$ for $20 \mathrm{~min}$, and triple rinsed with distilled water. The seeds were kept in a BOD (Biochemical Oxigen Demand) at constant temperature $20^{\circ} \mathrm{C}$, a photoperiod of $12 \mathrm{~h}$ (light/dark) and 1,200 lux. Germination was evaluated at 5 and 14 days, considering coleoptile/radicle protrusion. Nongerminated seeds were submitted to the tetrazolium test at a concentration $0.5 \%$ at $30{ }^{\circ} \mathrm{C}$ for $6 \mathrm{~h}$ (ISTA, 2014).

The total soil seed bank was obtained by summing seedlings emerged in the greenhouse and viable seeds that did not germinate, evaluated by the tetrazolium test.

$\Sigma_{\text {total soil seed bank }}=\Sigma_{\text {greenhouse germination }}+\Sigma_{\text {viable seeds tetrazolium test }}$

The plant population was evaluated by the number of emerged seedlings on ten random samples at each plot using a sample frame $\left(1.0 \mathrm{~m}^{2}\right)$ during the initial development of the winter crops (20 days after emergence - June) from 2011 to 2013.

\section{Statistical analysis}

Data on annual ryegrass population and soil seed bank were tested for normality using the Shapiro-Wilk test and then subjected to the analysis of variance $(p<$ 
0.05). The total soil seed bank was converted to seeds $\mathrm{m}^{-2}$ and the means for each plot were compared by the Tukey test $(p<0.05)$.

\section{Results and Discussion}

The total soil seed bank and population of Italian ryegrass showed statistical differences between crop rotation and tillage systems after long-term for all sampled
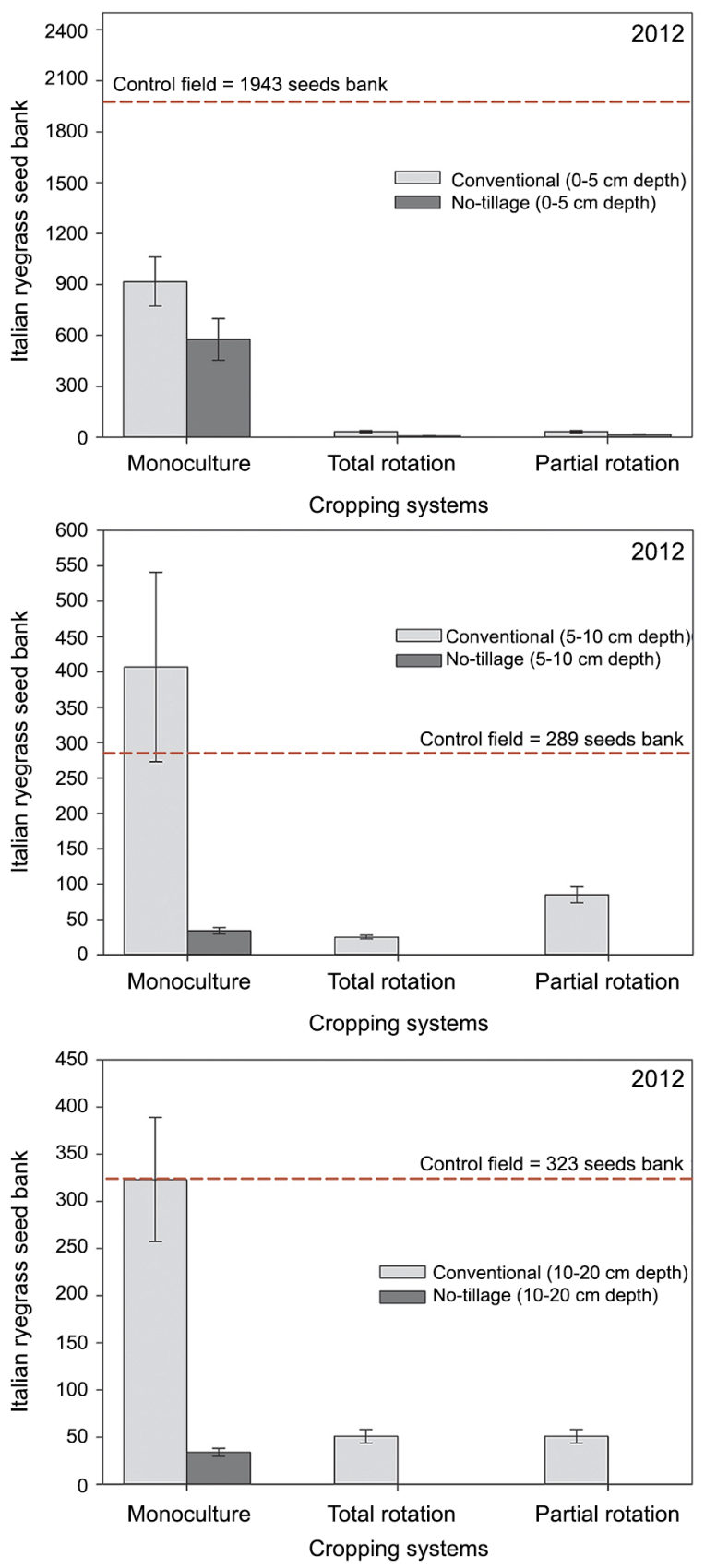

soil depths (Figures 3 and 4). The evaluation of vertical distribution of the seed bank showed greater number of the Italian ryegrass seeds at $0-5 \mathrm{~cm}$ soil layer for all cropping systems in 2012 and 2013 (Figure 3).

In both years, the use of monoculture during winter and summer $\left(\mathrm{M}_{1}\right)$ under conventional and no-tillage systems showed a greater number of Italian ryegrass seeds than the systems with partial $\left(\mathrm{M}_{3}\right)$ or total rotation $\left(\mathrm{M}_{2}\right)$ at all depths sampled (Figure 3). For the monoculture
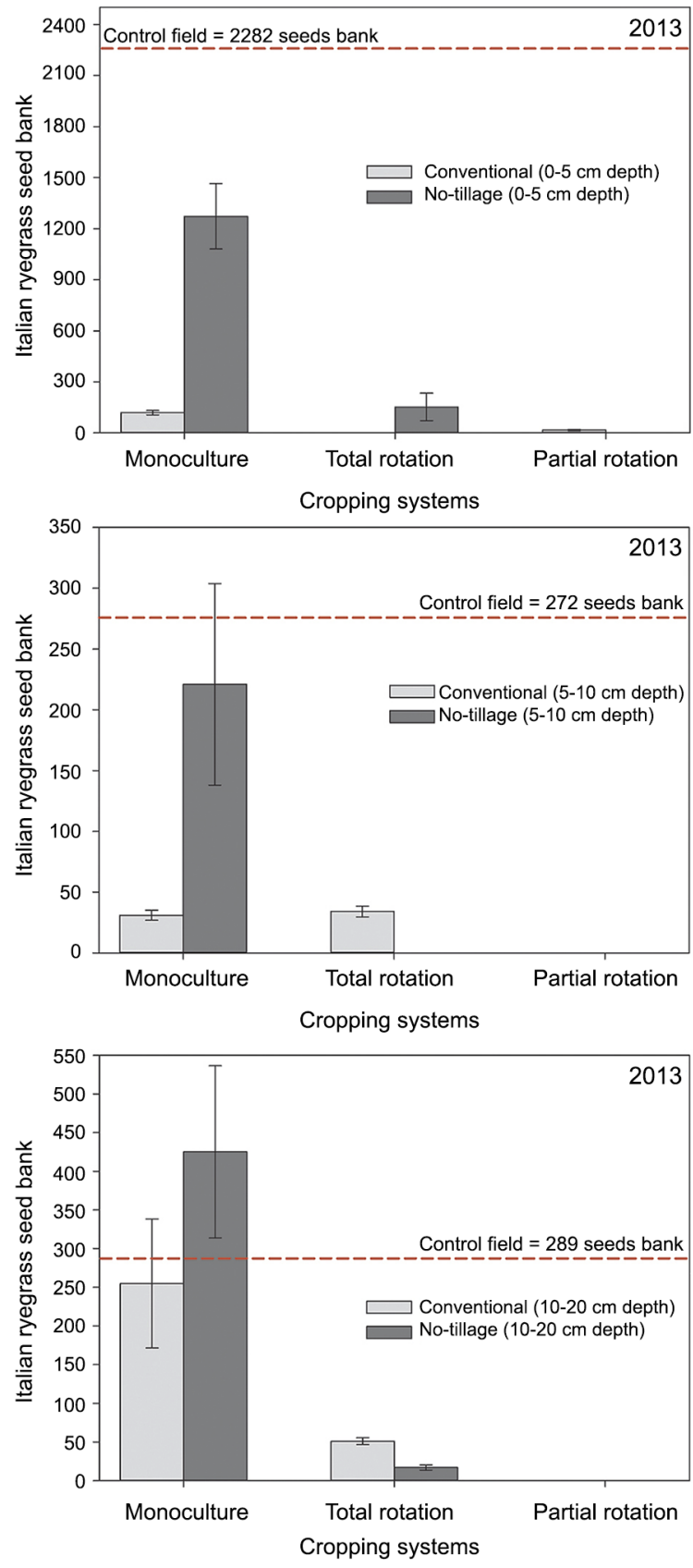

Figure 3 - Soil seed bank of Italian ryegrass (seeds $\mathrm{m}^{-2}$ ) at three depths under different tillage (conventional and no-tillage) and cropping systems $\left(M_{1}, M_{2}\right.$ and $\left.M_{3}\right)$ after long-term management. Bars on each column are standard errors of the means. 
cropping system $\left(\mathrm{M}_{1}\right)$ at $0-5 \mathrm{~cm}$ soil depth layer, the soil seed bank was on average $50 \%$ lower for conventional and $12 \%$ lower for no-tillage systems when compared to the control plot $\left(\mathrm{M}_{4}\right)$. For the soil tillage systems, the seed bank in the upper soil depth layer in the conventional cultivation was, on average, $43 \%$ lower than the no-tillage system (Figure 3, Table 3).

The input of new seeds after ripening occur mainly due to the high reproductive potential of weeds as well as the absence of crop rotation and alternative chemical control, affecting the seed bank dynamics. A recent study reported strong accumulation of grass seeds in monoculture cropping systems combined with non-inversion tillage (Scherner et al., 2016). Similar results demonstrated that no-tillage systems might favor the initial accumulation of weed seeds in the soil surface; however, they reduced the seed bank in the long-term due to lower seed longevity and higher predation (Anderson, 2008). The reduced size of Italian ryegrass seeds can affect the reserve amounts and favor microbial degradation on the soil surface and/ or deterioration in conventional-tillage systems, due to soil disturbance and abrupt changes in soil moisture and temperature, resulting in significant germination viability losses (Galvan et al., 2015).

The dynamic of soil seed banks is complex, presenting temporal changes, wherein seed persistence can be related to longevity, including the interaction of many factors, such as dormancy, environmental conditions, and
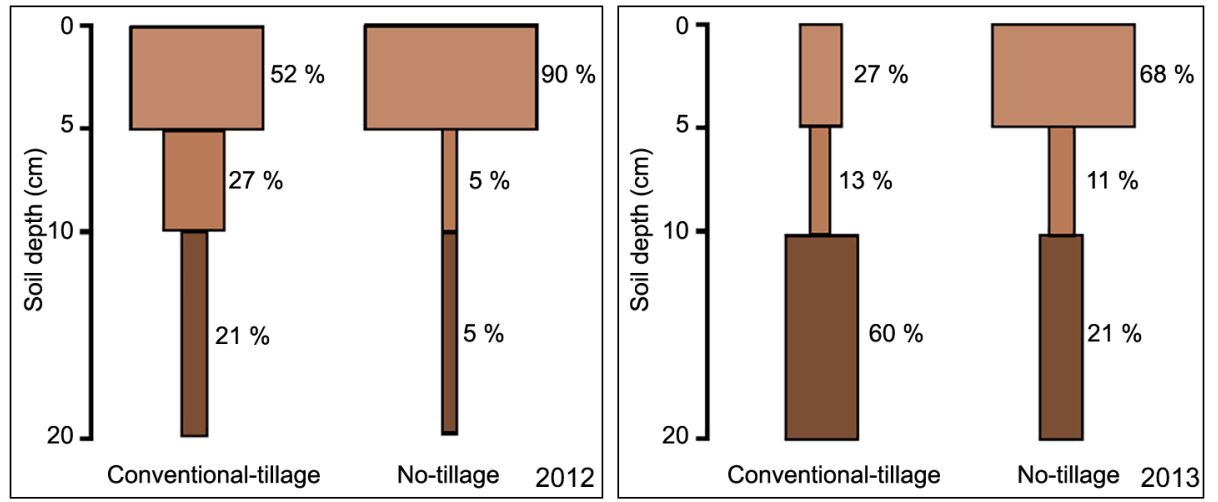

Figure 4 - Distribution of Italian ryegrass seeds at different depths for the conventional-tillage and no-tillage systems. Percentage obtained only in the tillage soil management.

Table 3 - Soil seed bank at three depths and Italian ryegrass population in fields with differential cropping and tillage systems.

\begin{tabular}{|c|c|c|c|c|}
\hline \multirow{3}{*}{ Cropping systems } & \multicolumn{2}{|c|}{2012} & \multicolumn{2}{|c|}{2013} \\
\hline & Conventional & No-tillage & Conventional & No-tillage \\
\hline & \multicolumn{4}{|c|}{$0-5 \mathrm{~cm}$ depth } \\
\hline Monoculture $\left(\mathrm{M}_{1}\right)$ & $917( \pm 144.7)^{*}$ & $577( \pm 121.9)$ & $119( \pm 13.2)$ & $1273( \pm 192.5)$ \\
\hline Total rotation $\left(\mathrm{M}_{2}\right)$ & $32( \pm 6.6)$ & $9.0( \pm 1.7)$ & $0.0( \pm 0.1)$ & $153( \pm 80.3)$ \\
\hline Partial rotation $\left(\mathrm{M}_{3}\right)$ & $34( \pm 6.7)$ & $17( \pm 3.3)$ & $17( \pm 3.1)$ & $0.0( \pm 0.1)$ \\
\hline Control plot $\left(\mathrm{M}_{4}\right)$ & \multicolumn{2}{|c|}{$1943( \pm 213.6)$} & \multicolumn{2}{|c|}{$2282( \pm 238.1)$} \\
\hline Cropping sytems & \multicolumn{4}{|c|}{ 5-10 cm depth } \\
\hline Monoculture $\left(\mathrm{M}_{1}\right)$ & $407( \pm 134.1)$ & $34( \pm 4.5)$ & $31( \pm 4.0)$ & $221( \pm 82.8)$ \\
\hline Total rotation $\left(\mathrm{M}_{2}\right)$ & $25( \pm 2.5)$ & $0.0( \pm 0.1)$ & $34( \pm 4.4)$ & $0.0( \pm 0.1)$ \\
\hline Partial rotation $\left(\mathrm{M}_{3}\right)$ & $85( \pm 11.3)$ & $0.0( \pm 0.1)$ & $0.0( \pm 0.2)$ & $0.0( \pm 0.1)$ \\
\hline Control plot $\left(\mathrm{M}_{4}\right)$ & \multicolumn{2}{|c|}{$289( \pm 49.2)$} & \multicolumn{2}{|c|}{$272( \pm 84.2)$} \\
\hline Cropping systems & \multicolumn{4}{|c|}{$10-20 \mathrm{~cm}$ depth } \\
\hline Monoculture $\left(\mathrm{M}_{1}\right)$ & $323( \pm 66)$ & $34( \pm 4.3)$ & $255( \pm 83.4)$ & $425( \pm 111.2)$ \\
\hline Total rotation $\left(\mathrm{M}_{2}\right)$ & $51( \pm 7.1)$ & $0.0( \pm 0.1)$ & $51( \pm 4.4)$ & $17( \pm 3.3)$ \\
\hline Partial rotation $\left(\mathrm{M}_{3}\right)$ & $50( \pm 7.0)$ & $0.0( \pm 0.0)$ & $0.0( \pm 0.1)$ & $0.0( \pm 0.0)$ \\
\hline Control plot $\left(\mathrm{M}_{4}\right)$ & \multicolumn{2}{|c|}{$323( \pm 62.6)$} & \multicolumn{2}{|c|}{$289( \pm 67.3)$} \\
\hline Cropping systems & \multicolumn{4}{|c|}{ Italian ryegrass population } \\
\hline Monoculture $\left(\mathrm{M}_{1}\right)$ & $54( \pm 19.4)$ & $409( \pm 117.5)$ & $14( \pm 6.9)$ & $384( \pm 88.7)$ \\
\hline Total rotation $\left(\mathrm{M}_{2}\right)$ & $14( \pm 7.2)$ & $10( \pm 5.4)$ & $9.0( \pm 3.4)$ & $2.0( \pm 1.7)$ \\
\hline Partial rotation $\left(\mathrm{M}_{3}\right)$ & $4.0( \pm 2.4)$ & $8.0( \pm 3.6)$ & $21( \pm 9.8)$ & $40( \pm 16.5)$ \\
\hline Control plot $\left(\mathrm{M}_{4}\right)$ & \multicolumn{2}{|c|}{$478( \pm 93.8)$} & \multicolumn{2}{|c|}{$798( \pm 121.1)$} \\
\hline
\end{tabular}

*Means with the standard errors (between parentheses) from ten samplings in each cropping system. 
biological processes (Graeber et al., 2012). For example, soil disturbance due to harrowing can help to control weeds or, on the other hand, ploughing can enhance seed longevity by reducing seedling emergence and keeping seeds viable for longer periods (Melander et al., 2013). The conventional management is a good opportunity for weed control with population reduction of annual weeds in cropping systems that include the use of ploughing or harrowing, offering an efficient control (Renton and Flower, 2015). However, none of these practices alone provides adequate weed control; however, when used in integrated weed management programs, they can protect yield potential, reduce the selection pressure for weed resistance, and keep weed populations at lower levels. Effectiveness of long-term weed management programs in cropping systems with crop rotation and chemical control reduced the rigid ryegrass seed bank after four years in Australia (Kleemann et al., 2016).

Our results demonstrated the importance of integrated weed management where total or partial rotation in no-tillage or conventional systems, associated with different chemical control, reduce the seed bank of Italian ryegrass more than 95,60 , and $80 \%$ in 0 to 5 , 5 to 10 , and 10 to $20 \mathrm{~cm}$ layers, respectively, compared to the control plot (Figure 3, Table 3). The evaluation of monoculture $\left(M_{1}\right)$ showed a significant reduction at all depths; however, the most significant reductions were observed for the no-tillage system under total and partial rotation, where the seed bank was $90 \%$ smaller than the control plot in 2012 and 2013 (Figure 3, Table 3). Our observations suggest three main reasons for the reduction of the soil seed bank: a) rotation during the winter using black oat, black oat + vetch or radish exhibit hindered development or affected seed germination of Italian ryegrass; b) summer rotation with corn reduced the input of new seeds of Italian ryegrass after ripening because corn sowing occurs, on average, two months before soybean, and c) the no-tillage system, along with the use of different chemical herbicides after long term, reduces the soil seed bank because the environmental conditions at soil surface favored seed germination and reduced dormancy, besides exposing seeds to predation, reducing inputs.

Similar strategies to manage weed density include reducing inputs by decreasing seed production, stimulating seed death or limiting seedling emergence through cover crops (Swanton and Booth, 2004). For example, crop competition is an important approach to manage weeds, especially in fields with herbicide resistance and crops with limited chemical options, because the use of more competitive winter crops, such as wheat (Triticum aestivum L.), oats (Avena sativa L.), and radish (Raphanus sativus L.), can provide better control of weeds, such as Italian ryegrass, and reduce the seed bank, preventing weed infestations (Bajwa et al., 2017). The utilization of corn in cropping systems is another way to reduce the seed banks of Italian ryegrass because the crop has a high suppression capacity and pre-emergence chemical management occurs when Italian ryegrass plants are in the vegetative stage, preventing the input of new seeds into the soil (Galvan et al., 2015; Jha et al., 2017). Moreover, chemical options for weed control in corn are broader due to the possibility of using herbicides in pre- and post-emergence with different action mechanisms. Similar results with low weed densities were observed after the use of different herbicides in combination with soil tillage or in crop rotation systems (Colbach et al., 2017).

Comparing seed distribution in the soil profile in conventional-tillage and no-tillage systems without the effects of cropping systems management, the results showed that 52 and $90 \%$ of the seeds occurred at $0-5 \mathrm{~cm}$ layer in 2012 and, 27 and $68 \%$ in 2013 (Figure 4). The use of mouldboard ploughing for conventional-tillage caused soil inversion affecting seed distribution from 2012 to 2013 with a reduction of $25 \%$ at 0-5 cm layer, and an increase of $39 \%$ in the 10-20 soil layer (Figure 4). Conventional-tillage presented a uniform distribution of seeds throughout the soil profile than no-tillage due to the inversion of the soil seeds caused by plowing operations (Figure 4). For notillage, the larger number of seeds remained at the $0-5 \mathrm{~cm}$ layer. Similar results were found in Poa annua L. under systems with soil inversion where vertical distribution was more uniform than no-inversion tillage and contributed to preventing seedling establishment due to seed burial and unfavorable conditions for germination (Scherner et al., 2016). On the other hand, the reduction of seed number in no-tillage can be associated with chemical control, different dormancy levels, and increased predation and deterioration. Soil tillage is the main factor for vertical distribution of weed seeds within the soil profile. For example, plowed fields with frequent disturbance favor a uniform vertical distribution in the soil profile while in reduced tillage systems, most weed seeds remain at or near the soil surface (Clements et al., 1996). Furthermore, seed burial has a great influence on germination with shallow-buried seeds showing higher germination than seeds on the soil surface or buried deeply and, are highly relevant to management of the weed seed bank (Goggin et al., 2012).

For seedling emergence before the sowing of winter crops, the results show a greater number of seedlings of Italian ryegrass for $M_{1}$ under no-tillage than $M_{2}$ and $M_{3}$, regardless of the soil tillage system (Figure 5, Table 3). In 2012 and 2013, the population of Italian ryegrass in $M_{1}$ under no-tillage was 384 and 409 plants $\mathrm{m}^{-2}$, respectively, which is more than $86 \%$ greater than under conventional tillage. Preliminary responses of the Italian ryegrass population sampled in 1990 in the same experiment, reported an average population of 42 and 24 plants $\mathrm{m}^{-2}$ for no-tillage and conventional-tillage (Ruedell, 1995). Additionally, our results showed a strong reduction of Italian ryegrass seedlings in the cropping systems with total or partial rotation, regardless of the tillage system, where the population was lower than 15 plants $\mathrm{m}^{-2}$, except for partial rotation in 2012 with 21 and 40 plants $\mathrm{m}^{-2}$ for conventional and no-tillage, respectively (Figure 5, Table 3). The effects of mechanical and chemical methods, 

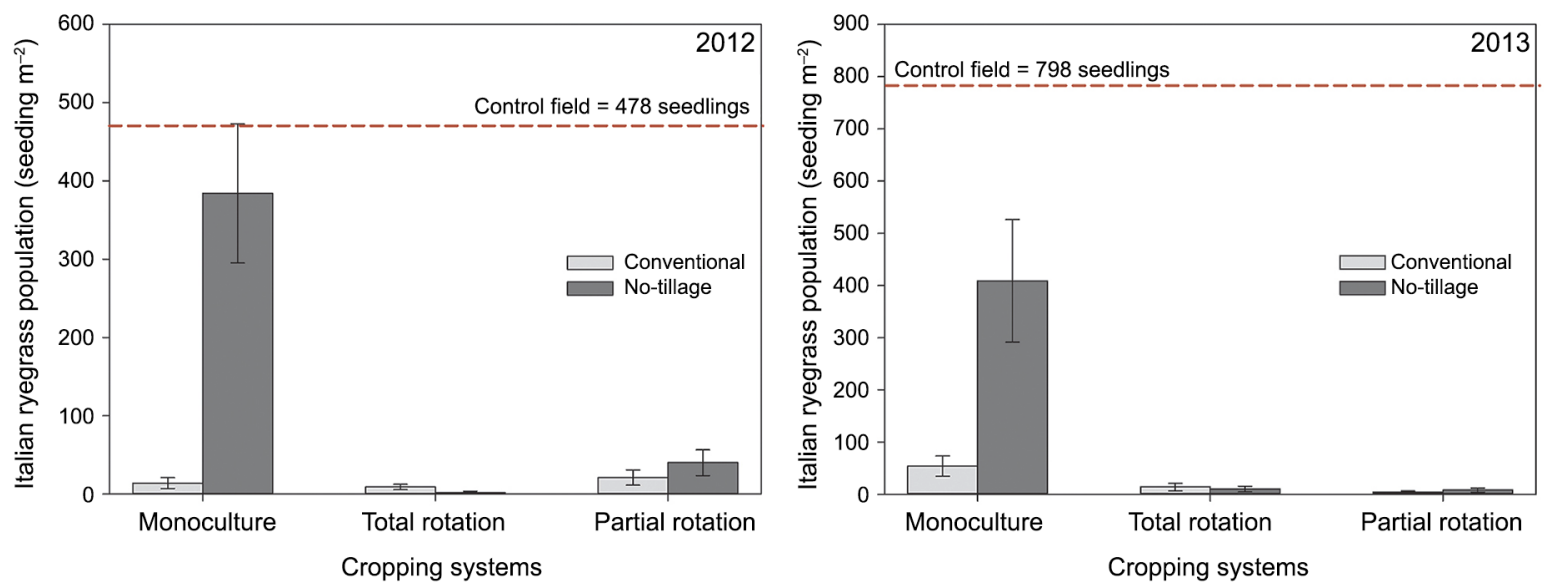

Figure 5 - Italian ryegrass population (plants $m^{-2}$ ) under different tillage (conventional and no-tillage) and cropping systems $\left(M_{1}, M_{2}\right.$ and $\left.M_{3}\right)$ after long-term management. Bars on each column are standard errors of the means.

when combined, demonstrated better efficacy on Italian ryegrass control and seed bank reduction in corn and soybean crops than management practices applied alone (Pannacci and Tei, 2014).

Other population variations observed in $M_{1}$ for the conventional and no-tillage systems can be associated with plant death after disturbance, seed burial, increased germination rate, seed deterioration and predation, especially in Italian ryegrass, which has small seed longevity. Similar results with higher density of annual grass weeds were found after frequent cropping winter cereals combined with no-tillage (Scherner et al., 2016). In contrast, partial or total rotation were important to reduce seed inputs through a better competition of crops, such as oat and radish (cultural and physical control) when compared to wheat monoculture, allowing the use of alternative herbicides for weed control. After long-term, our results demonstrated that weed seed density was, on average, $97 \%$ and $99 \%$ lower for $M_{2}$ and $M_{3}$ when compared to the control plot, respectively.

Overall, the models of weed dynamics to estimate future infestations include the weed population in the seed bank and management actions (Galvan et al., 2015; Borgy et al., 2015). Thus, the interaction of crop rotation and soil tillage management with weed chemical control can create unfavorable conditions for weed development and reduce input of seeds, contributing to the decrease of weed populations. These results indicate that strategies to prevent future Italian ryegrass infestations should not only focus on decreasing weed density, but also include practices to reduce weed seed banks that can minimize yield losses and avoid herbicide resistance.

The soil seed bank of Italian ryegrass, especially at 0-5 cm soil depth layer, was lower for all cropping systems compared to the control plot. Total or partial rotation practices are more effective in reducing the soil seed bank, regardless of the tillage system. For conventionaltillage, the results showed more uniform distribution of seeds in the soil profile, allowing to reduce Italian ryegrass populations in monoculture crops.

\section{Acknowledgements}

The first author thanks the Coordination of Higher Education Personnel (CAPES) for the scholarship, and the Federal University of Santa Maria and Cooperativa Central Gaúcha LTDA. Too, thank you so much to the researcher Dr. Jackson Ernani Fiorin for the availability of the area and work developed over time. Also thanks to contributions from researchers and students involved in this work.

\section{Authors' Contributions}

Conceptualization: Guareschi, A.; Cechin, J.; Maldaner, I.C.; Bianchi, M.A.; Machado, S.L.O. Data acquisition: Guareschi, A.; Cechin, J. Data analysis: Guareschi, A.; Cechin, J.; Maldaner, I.C.; Bianchi, M.A.; Machado, S.L.O. Design of methodology: Guareschi, A.; Cechin, J.; Maldaner, I.C.; Bianchi, M.A.; Machado, S.L.O. Writing and editing: Guareschi, A.; Cechin, J.; Machado, S.L.O.

\section{References}

Anderson, R.L. 2008. Diversity and no-till: keys for pest management in the U.S. Great Plains. Weed Science 56: 141-145.

Armengot, L.; José-María, L.; Chamorro, L.; Sans, F.X. 2017. Avena sterilis and Lolium rigidum infestations hamper the recovery of diverse arable weed communities. Weed Research 57: 278-286.

Bajwa, A.A.; Walsh, M.; Chauhan, B.S. 2017. Weed management using crop competition in Australia. Crop Protection 95: 8-13.

Blackshaw, R.E.; Larney, F.J.; Lindwall, C.W.; Watson, P.R.; Derksen, D.A. 2001. Tillage intensity and crop rotation affect weed community dynamics in winter wheat cropping systems. Canadian Journal of Plant Science 81: 805-813. 
Brown, D. 1991. Estimating the composition of a forest seed bank: a comparison of the seed extraction and seedling emergence methods. Canadian Journal of Plant Science 70: 1603-612.

Borgy, B.; Reboud, X.; Peyard, N.; Sabbadin, R.; Gaba, S. 2015. Dynamics of weeds in the soil seed bank: A hidden markov model to estimate life history traits from standing plant time series. PlosOne 10: e0139278.

Chauhan, B.S.; Gill, G.S.; Preston, C. 2006. Influence of tillage systems on vertical distribution, seedling emergence and persistence of rigid ryegrass (Lolium rigidum) seed bank. Weed Science 54: 669-676.

Clements, D.R.; Benoit, D.L.; Swanton, C.J. 1996. Tillage effects on weed seed return and seedbank composition. Weed Science 44: 314-322.

Colbach, N.; Fernieri, A.; Le Corre, V.; Messéan, A.; Darmency, H. 2017. Simulating changes in cropping practises in conventional and glyphosate-tolerant maize. I. Effects on weeds. Environmental Science and Pollution Research International 24: 11582-11600.

Collavo, A.; Strek, H.; Beffa, R. 2013. Management of an ACCaseinhibitor resistant Lolium rigidum population based on the use of ALS inhibitors: weed population evolution observed over a 7 year fieldscale investigation. Pest Management Science 69: 200208.

Davis, A.S.; Anderson, K.I.; Hallett, S.G.; Renner, K.A. 2006. Weed seed mortality in soils with contrasting agricultural management histories. Weed Science 54: 291-297.

Fernández-Moreno, P.T.; Cruz, R.A.; Smeda, R.J.; Prado, R. 2017. Differential resistance mechanisms to glyphosate result in fitness cost for Lolium perenne and L. multiflorum. Frontiers in Plant Science 8: 1796.

Galvan, J.; Rizzardi, M.A.; Peruzzo, S.T.; Overejo, R.F. 2015. Evolution of ryegrass seed banks depending on soil tillage and crops. Planta Daninha 33: 183-191.

Goggin, D.E.; Powles, S.B.; Steadman, K.J. 2012. Understanding Lolium rigidum seeds: the key to managing a problem weed? Agronomy 2: 222-239.

Graeber, K.; Nakabayashi, K.; Miatton, E.; Leubner-Metzger, G.; Soppe, W.J.J. 2012. Molecular mechanisms of seed dormancy. Plant, Cell \& Environment 35: 1769-1786.

Harker, K.N. 2013. Slowing weed evolution with integrated weed management. Canadian Journal of Plant Science 93: 759-764.

Harker, N.; O`Donovan, J.T. 2013. Recent weed control, weed management, and integrated weed management. Weed Technology 27: 1-11.

International Seed Testing Association [ISTA]. 2014 International Rules for Seed Testing. International Seed Testing Association, Bassersdorf, Switzerland.

Jha, P.; Kumar, V.; Godara, R.K.; Chauhan, B.S. 2017. Weed management using crop competition in the United States: a review. Crop Protection 95: 31-37.

Karn, E.; Jasieniuk, M. 2017. Genetic diversity and structure of Lolium perenne ssp. multiflorum in California vineyards and orchards indicate potential for spread of herbicide resistance via gene flow. Evolutionary Applications 10: 616-629.

Kleemann, S.G.L.; Preston, C.; Gill, G.S. 2016. Influence of management on long-term seedbank dynamics of Rigid ryegrass (Lolium rigidum) in cropping systems of Southern Australia. Weed Science 64: 303-311.
Melander, B.; Munier-Jolain, N.; Charles, R.; Wirth, J.; Schwarz, J.; Van der Weide, R.; Bonin, L.; Jensen, P.K.; Kudsk, P. 2013. European perspectives on the adoption of non-chemical weed management in reduced tillage systems for arable crops. Weed Technology 27: 231-240.

Norris, R.F. 2007. Weed fecundity: current status and future needs. Crop Protection 26: 182-188.

Norsworthy, J.K.; Ward, S.M.; Shaw, D.R.; Llewellyn, R.S.; Nichols, R.L.; Webster, T.M.; Bradley, K.W.; Frisvold, G.; Powles, S.B.; Burgos, N.R.; Witt, W.W.; Barrett, M. 2012. Reducing the risks of herbicide resistance: best management practices and recommendations. Weed Science 60: 31-62.

Owen, M.J.; Martinez, N.J.; Powles, S.B. 2014. Multiple herbicideresistant Lolium rigidum (annual ryegrass) now dominates across the western Australian grain belt. Weed Research 54: 314-324.

Pannacci, E.; Tei, F. 2014. Effects of mechanical and chemical methods on weed control: weed seed rain and crop yield in maize, sunflower and soybean. Crop Protection 64: 51-59.

Price, J.N.; Wright, B.R.; Gross, C.L.; Whalley, W.R.D.B. 2010. Comparison of seedling emergence and seed extraction techniques for estimating the composition of soil seed banks. Methods in Ecology and Evolution 1: 151-157.

Renton, M.; Flower, K.C. 2015. Occasional mouldboard ploughing slows evolution of resistance and reduces long term weed populations in no-till systems. Agricultural Systems 139: 66-75.

Ruedell, J. 1995. No-tillage in the Cruz Alta Region = Plantio direto na Região de Cruz Alta. FUNDACEP, Cruz Alta, RS, Brazil (in Portuguese).

Scherner, A.; Melander, B.; Kudsk, P. 2016. Vertical distribution and composition of weed seeds within the plough layer after eleven years of contrasting crop rotation and tillage schemes. Soil and Tillage Research 161: 135-142.

Shaner, D.L.; Beckie, H.J. 2014. The future for weed control and technology. Pest Management Science 70: 1329-1339.

Soil Survey Staff. 2014. Keys to Soil Taxonomy. 12ed. USDA-NRCS, Washington, DC, USA.

Swanton, C.J.; Booth, B.D. 2004. Management of weed seedbanks in the context of populations and communities. Weed Technology 18: 1496-1502.

Vargas, L.; Roman, E.S. 2005. Selectivity and efficacy of herbicides to winter cereals. Revista Brasileira de Herbicidas 4: 1-10 (in Portuguese, with abstract in English).

Vargas, L.; Adegas, F.; Gazziero, D.; Karam, D.; Agostinetto, D.; Silva, W.T. 2016. Weed herbicide-resistance in Brazil: historic, distribution, economic damage, management, and prevention = Resistência de plantas daninhas a herbicidas no Brasil: histórico, distribuição, impacto econômico, manejo e prevenção. p. 219-240. In: Maschaede, K.; Gazziero, D.P., eds. Glyphosate age: agriculture, environmental, and human = A era glyphosate: agricultura, meio ambiente e homem. Editora Midiograf II, Londrina, PR, Brazil (in Portuguese).

Voll, E.; Adegas, F.S.; Gazziero, D.L.P.; Brigheti, A.M.; Oliveira, M.C.N. 2003. Sampling of weed seedbank and emerged populations. Pesquisa Agropecuária Brasileira 38: 211-218 (in Portuguese, with abstract in English). 